\title{
Effect of silicon and mineral extract on heavy metals balance and accumulation rate in the muscle tissue of poultry
}

\author{
S. F. Razanov, G. V. Hutsol, L. I. Posternak, S. P. Kovaleva \\ Vinnytsia National Agrarian University \\ 3 Sonyachna St., Vinnytsia, 21008, Ukraine \\ E-mail:nv.vn@ukr.net,gucolg@ukr.net,posternak@vsau.vin.ua \\ Zhytomyr Branch State Institution Soils Protection Institute of Ukraine \\ Zhytomir, 10020, Ukraine
}

Received: 12.11.2019. Accepted: 25.12.2019

\begin{abstract}
The level of contamination of poultry fodder raw material, which includes $30 \%$ of corn, $55 \%$ of wheat, $5 \%$ of oats, $5 \%$ of barley and $5 \%$ of sunflower meal, by heavy metals (lead, cadmium, zinc, copper) in the zone of intensive farming of the Right-bank Forest-steppe of Ukraine is shown. The impact of silicon and mineral extract on the intensity of heavy metals (lead, cadmium, zinc, copper) accumulation in the edible parts of poultry, namely in the red and white meat, liver and skin is studied. It has been revealed that there is an excess of MAC in cadmium by 2.1 times in the fodder wheat and by 3.0 times in the sunflower meal (Medical and Biological Requirements 5061-89) in the zone of intensive farming of the Right-bank Forest-steppe of Ukraine. The replacement of $10 \%$ of water with siliconand mineral water extract in the poultry diet under their keeping at households contributes to increase the removal of lead from their bodies by $27.4 \%$, cadmium - by $30.2 \%$, zinc - by $20 \%$, and copper - by $16.3 \%$. We determined that the use of silicon and mineral water extract in the poultry diet reduced the concentration of lead by 1.6 times in the liver, by 1.1 times in the white meat and by 1.02 times in the red meat; it reduced the concentration of cadmium by $1.2,1.6$, and 1.2 times; reduced the concentration of zinc by $1.3,1.05$, and 1.8 times; the concentration of copper by $1.3,1.3$, and 1.4 times, respectively.
\end{abstract}

Key words: cadmium, copper, heavy metals, lead,poultry, zinc.

\section{Introduction}

The fodder raw material is a source of vital substances for animals, including poultry, and plays an important role in their existence (Razanov, 2008; Razanov 2010a, 2010b). When consuming feed the poultry provides their body with protein, fat, mineral substances, carbohydrates, vitamins and other vital substances (Ischenko, 2013; Kyryljuk, 2014). However, the fodder raw material can also be a source of harmful substances, namely heavy metals, leading to their accumulation in the poultry's tissues and considerably reducing the quality and safety of meat (Kulyk et al., 2003; Hutjens, 1991). The fodder raw material takes a leading place in this chain, because up to $95 \%$ of heavy metals come with nutrients into the poultry's body (Bomko et al., 2006; Toth et al., 2016).

The consumption of poultry's meat by the population (that makes $19 \%$ of the population's total need from all species of animals) leads to the accumulation of heavy metals in the human body having a negative impact on their health (Baker et al., 1994; Fuzhu et al., 2013). Nowadays there is an uptrend in the level of diseases for the population living in the zone of intensive farming, where the increase in the pollution of agricultural lands and fodder raw materials by heavy metals is observed (Kurkina, 2001; Simon, 2009).

Heavy metals threaten living organisms very much because their parts are in the exchange form (Nedashkivska, 2015; Pogorjelov, 2010). Under such conditions, heavy metals are in the constant circulation accumulating in the tissues of living organisms and causing the whole number of damages at the cellular, organ's and body's levels (Awad, 2006; El-Sharaky et al., 2007). Therefore, there is a need to control the translocation of heavy metals in the environment, as well as the obstacles to their migration along the chain of soil $\rightarrow$ vegetable fodder raw materials $\rightarrow$ poultry products $\rightarrow$ human organism (Razanov et al., 2015; Tkachuk, 2016). For this purpose, a number of sorbents are used, preferring ecological and natural means (Bomko et al., 2007; Reis et al., 2010).

The research of scientists has proved the high efficiency of the removal of heavy metals from the body of animals when using selenium (Pirovaet et al., 2010; Sendecka, 2014), as well as alumina and aluminosilicates (Beltcheva, 2013; Corzo et al., 2005) in their diet. 
A great deal of attention is also devoted to feed protections (Dyachenko et al., 2017; Wlazlo et al., 2016). Such feeds include: soybeans, fodder beets and apple squash (Dyachenko et al., 2015; Sollrad et al., 2013).

\section{Material and methods}

The study of the intensity of contamination of fodder raw material, the quality of chicken meat and the exchange of heavy metals in their body when using silicon and mineral extract into the diet was carried out in the conditions of intensive farming in the Right-Bank Forest-steppe of Ukraine. The study of the impact of silicon and mineral extract on the intensity of the accumulation of heavy metals in the poultry's meat was carried out under keeping the poultry at households. The poultry was kept on the areas with free access to vegetation and natural minerals of the soil. The Redbro breed of hens was used in the conducted researches.

The scheme of heavy metals balance included the preparatory period, the essence of which was to form experimental groups. The duration of this period was 7 days (Kononenko, 2000). During this period, the part of the water was gradually replaced with the silicon and mineral extract in the poultry of the experimental group. The second period was the main one. It was characterized by the replacement of water with $10 \%$ silicon and mineral extract in the poultry of the experimental group. The balance of heavy metals in the body of poultry was carried out according to the generally accepted method, which provided the formation of poultry from control and experimental groups consisting of 4 heads of average weight, the difference of which did not exceed the average weight of the group in the general (Ibatullin, 2007). The poultry of each group were placed into separate cages. The fertilization and selection of the manure was carried out from the poultry of both groups at the same time.

The conditions for poultry's keeping and care were the same. The poultry were continuously provided with feed and water. Every day we weighed the amount of feed and water having been given to the poultry, as well as their daily balance. The manure samples were taken every day, weighed and stored in a preserved state in the refrigerated chamber until the end of the experiment. During the research the poultry of control and experimental groups were given the same feed. The only difference was that $10 \%$ of water were replaced by the silicon and mineral extractin the experimental group.

\section{Results}

The analysis of the poultry's diet, which are kept at the households, has shown that it is not always balanced by nutrients, especially mineral. As a rule, the replenishment of the poultry's diet with mineral substances is taking place under their free access to the minerals in the soil.

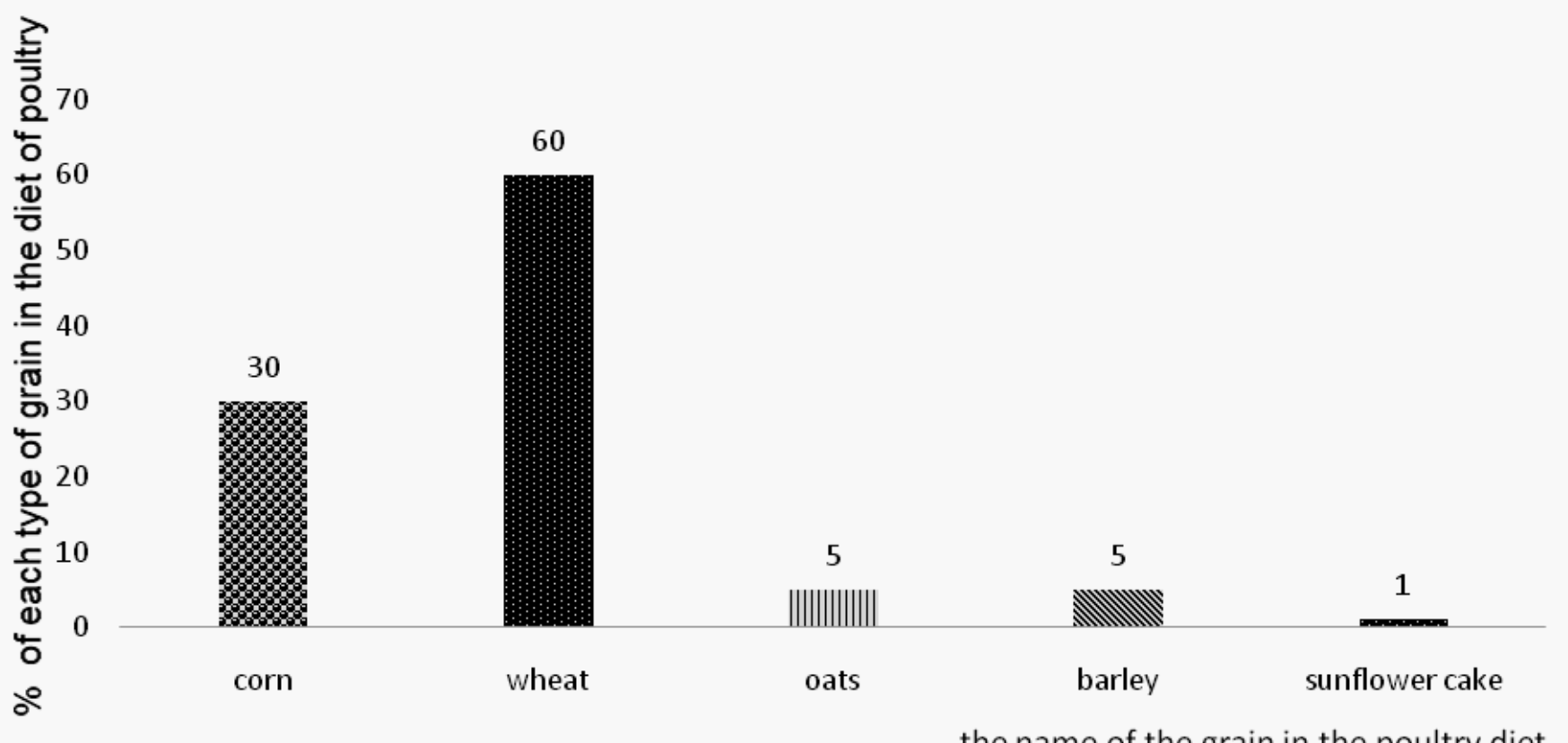

the name of the grain in the poultry diet

Fig. 1 Structure of poultry diet

When analyzing the poultry's diet, it should be noted that it includes 30\% of corn, 55\% of wheat, 5\% of oats, $5 \%$ of barley and sometimes up to $5 \%$ of sunflower meal. In some cases, it also includes mixed feed, which is used for poultry, mainly at an early age (1-30 days). 
Table 1. Contamination of fodder raw materials by heavy metals

\begin{tabular}{|c|c|c|c|c|c|c|c|c|}
\hline $\begin{array}{c}\text { Components } \\
\text { of poultry } \\
\text { diet }\end{array}$ & $\mathrm{Pb}$ & MAC & $\mathrm{Cd}$ & MAC & $\mathrm{Zn}$ & MAC & $\mathrm{Cu}$ & MAC \\
\hline Corn & $0.07 \pm 0.004$ & 0.5 & $0.01 \pm 0.006$ & 0.3 & $0.05 \pm 0.04$ & 50 & $1.13 \pm 0.004$ & 30 \\
\hline Wheat & $0.4 \pm 0.04$ & 0.5 & $0.21 \pm 0.004$ & 0.1 & $11.97 \pm 0.002$ & 50 & $25.60 \pm 0.004$ & 30 \\
\hline Oats & $0.09 \pm 0.005$ & 5.0 & $0.017 \pm 0.0004$ & 0.3 & $2.34 \pm 0.002$ & 50 & $13.12 \pm 0.004$ & 30 \\
\hline Barley & $0.3 \pm 0.04$ & 5.0 & $0.03 \pm 0.004$ & 0.3 & $4.53 \pm 0.002$ & 50 & $11.30 \pm 0.002$ & 30 \\
\hline $\begin{array}{l}\text { Sunflower } \\
\text { meal }\end{array}$ & $0.4 \pm 0.04$ & 0.5 & $0.3 \pm 0.04$ & 0.1 & $0.99 \pm 0.002$ & 50 & $7.12 \pm 0.004$ & 30 \\
\hline
\end{tabular}

The results of the research on the intensity of fodder raw materials contamination by heavy metals in the poultry's diet (Table 1) showed that the concentration of lead, cadmium, zinc and copper in corn was lower in comparison with MAC (Medical and Biological Requirements 5061-89) by 7.1, 30, 1000, and 26.5 times, respectively. The concentration of lead, zinc and copper in wheat, was lower than MAC by $1.2,4.2$, and 1.2 times, respectively, while the concentration of cadmium was by 2.1 times higher than MAC. The concentration of lead, cadmium, zinc and copper in oats was lower than MAC by 55.5, 17.6, 21.4 and 2.3 times, respectively. There was less of lead, cadmium, zinc, and copper in barley in comparison with MAC by 16.7, 11.5, 11, and 2.6 times, respectively. Sunflower meal contained less of lead, zinc and copper by $1.25,50.5$ and 4.2 times, respectively, but it contained by 3 times more of cadmium.

Compared to MAC, the highest intensity of contamination of fodder raw materials in the poultry's diet was observed in wheat. Thus, there was more of lead, cadmium, zinc and copper in wheat in comparison with corn by 5.7, 21, 239.4, and 22.6 times, respectively. Compared to wheat, oats contained less of lead, cadmium, zinc and copper by 4.4, 12.3, 5.1, and 1.9 times, respectively. The concentration of lead was by 1.3 times, of cadmium - by 8 times, of zinc - by 2.6 times and that one of copper - by 2.3 times less in barley than in wheat. Sunflower meal had the lower content of zinc by 12 times, of copper - by 3.6 times and that one of cadmium - by 1.4 times in comparison with wheat.

Table 2. Content of heavy metals in feed

\begin{tabular}{lccccc}
\hline \multicolumn{1}{c}{ Components of poultry diet } & \% in the diet & $\mathrm{Pb}$ & $\mathrm{Cd}$ & $\mathrm{Zn}$ & $\mathrm{Cu}$ \\
\hline Corn & 30 & 0.14 & 0.01 & 0.05 & 1.13 \\
Wheat & 55 & 0.8 & 0.21 & 0.017 & 2.34 \\
Oats & 5 & 0.018 & 0.026 & 4.53 & 11.97 \\
Barley & 5 & 0.06 & 0.3 & 0.99 & 7.12 \\
Sunflower meal & 5 & 0.8 & & & \\
\end{tabular}

When analyzing the coefficient of heavy metals danger in the poultry's fodder raw material (Table 2), it should be noted that it was the highest by lead in wheat and sunflower meal. In particular, compared to corn, oats and barley, the content of lead in wheat and sunflower meal was higher by 5.7,44.4 and 13.3 times, respectively. The highest content of cadmium in the poultry raw material was found in sunflower meal and it was $0.3 \mathrm{mg} \mathrm{kg}^{-1}$. Compared to corn, wheat, oats and barley, the concentration of cadmium in sunflower meal was higher by 30,1.4, 17.6 and 11.5 times, respectively. The highest coefficient of zinc danger was in wheat compared to corn, oats, barley and sunflower meal by 239.4, 5.1, 2.6 and 12.1 times, respectively. The coefficient of copper danger was the highest in corn by 22.6 times, in oats - by 1.9 times, in barley - by 2.3 times, and in sunflower meal by 3.6 times in comparison with wheat.

Thus, the excess of heavy metals in the poultry's raw material was detected by cadmium in wheat and sunflower meal on the research areas of the central Forest-steppe of Ukraine in the zone of intensive farming. At the same time, it should be noted that wheat and sunflower meal are characterized by high content of lead, though without exceeding MAC.

The analysis of poultry meat contamination by heavy metals (Table 3) showed that the concentration of lead in the skin, liver and white meat was lower than MAC by 50, 25 and 1.3 times, respectively. The content of lead in the red meat was at the level of maximum allowable concentration. The concentration of cadmium was higher than MAC by 1.8 times in the skin, by 4.8 times in the liver, by 1.2 times in the white meat and by 1.8 times in the red meat. The concentration of zinc in the skin, liver, white and red meat was lower by 2.8, 4.1, 10.7 and 109 times, respectively, compared to MAC. The content of copper in the skin, white and red meat was lower by $1.08,2.8$ and 1.6 times, respectively, while that one in the liver was by 1.5 times higher than MAC. 
Table 3. Content of heavy metals and microelements in some edible parts of poultry

\begin{tabular}{|c|c|c|c|c|c|c|c|c|}
\hline \multirow{3}{*}{ Experimental material } & \multicolumn{8}{|c|}{ Concentration of heavy metals $\mathrm{mg} \mathrm{kg}^{-1}$} \\
\hline & \multicolumn{2}{|c|}{$\mathrm{Pb}$} & \multicolumn{2}{|c|}{$\mathrm{Cd}$} & \multicolumn{2}{|c|}{$\mathrm{Zn}$} & \multicolumn{2}{|c|}{$\mathrm{Cu}$} \\
\hline & Actual & MAC & Actual & MAC & Actual & MAC & Actual & MAC \\
\hline Skin & $0.01 \pm 0.004$ & 0.5 & $0.09 \pm 0.004$ & 0.05 & $25.0 \pm 0.02$ & 70.0 & $4.6 \pm 0.04$ & 5.0 \\
\hline Liver & $0.02 \pm 0.004$ & 0.5 & $0.24 \pm 0.002$ & 0.05 & $16.8 \pm 0.04$ & 70.0 & $7.8 \pm 0.04$ & 5.0 \\
\hline White meat & $0.38 \pm 0.004$ & 0.5 & $0.06 \pm 0.004$ & 0.05 & $6.5 \pm 0.04$ & 70.0 & $17.4 \pm 0.04$ & 5.0 \\
\hline Red meat & $0.50 \pm 0.004$ & 0.5 & $0.09 \pm 0.004$ & 0.05 & $8.8 \pm 0.04$ & 70.0 & $31 \pm 0.02$ & 5.0 \\
\hline
\end{tabular}

Table 4. Content of heavy metals in poultry meat

\begin{tabular}{lcccc}
\hline \multicolumn{1}{c}{ Experimental material } & \multicolumn{4}{c}{ Concentration of an element's danger mg/kg } \\
& $\mathrm{Pb}$ & $\mathrm{Cd}$ & $\mathrm{Zn}$ & $\mathrm{Cu}$ \\
\hline Skin & 0.02 & 1.8 & 5 & 0.06 \\
Liver & 0.04 & 4.8 & 3.36 & 0.11 \\
White meat & 0.76 & 1.2 & 1.3 & 0.25 \\
Red meat & 1.0 & 1.8 & 1.7 & 0.44 \\
\hline
\end{tabular}

The coefficient of lead danger (Table 4) was the highest in the red meat, compared to the skin, liver and white meat by 50,25 and 1.3 times, respectively. The highest coefficient of cadmium danger was detected in the liver. In the comparison withthe skin, white and red meat, the coefficient of cadmium danger was higher in the liver by $2.6,4.0$ and 1.5 times, respectively. The coefficient of zinc danger was the highest in the poultry's skin, compared to the liver, white and red meat by $1.45,3.8$ and 2.9 times, respectively. The highest coefficient of copper danger was detected in the liver, in particular, compared to the skin, white and red meat by 1.6, 4.4 and 2.4 times, respectively.

The obtained results of the research on the study of the balance of heavy metals in the poultry' body when using the silicon and mineral extract in their diet (Table 5) showed a certain increase in the intensity of the removal of lead, cadmium, zinc and copper with non-digestible remnants of poultry's feed, which reduced their assimilation in the poultry's muscles. In particular, the use of silicon and mineral extract contributed to an increase in the removal of lead from poultry's body by $27.4 \%$, cadmium - by $30.2 \%$, zinc - by $20 \%$, and copper - by $16.3 \%$.

Table 5. Balance of heavy metals in the poultry body under silicon extract usage

\begin{tabular}{|c|c|c|c|c|c|}
\hline \multirow[t]{2}{*}{ Groups of poultry } & \multirow[t]{2}{*}{$\begin{array}{c}\text { That is come with feed in } \\
\text { average for day and night, } \\
\text { mg }\end{array}$} & \multicolumn{2}{|c|}{$\begin{array}{c}\text { That is removed with chicken } \\
\text { manure in average for day } \\
\text { and night }\end{array}$} & \multicolumn{2}{|c|}{$\begin{array}{l}\text { That is left in the body in average } \\
\text { for day and night }\end{array}$} \\
\hline & & mg & $\%$ & $\mathrm{mg}$ & $\%$ \\
\hline \multicolumn{6}{|c|}{ Balance of $\mathrm{Pb}$} \\
\hline 1 - control & $0.028 \pm 0.0004$ & $0.010 \pm 0.002$ & 35.7 & $0.018 \pm 0.0004$ & 64.3 \\
\hline 2 - experimental & $0.0285 \pm 0.00004$ & $0.018 \pm 0.0004^{* *}$ & 63.1 & $0.0105 \pm 0.00004 * \star *$ & 36.8 \\
\hline \multicolumn{6}{|c|}{ Balance of Cd } \\
\hline 1 - control & $0.013 \pm 0.0004$ & $0.006 \pm 0.0004$ & 46.1 & $0.007 \pm 0.004$ & 53.9 \\
\hline 2 - experimental & $0.0131 \pm 0.00004$ & $0.01 \pm 0.004$ & 76.3 & $0.0031 \pm 0.00003$ & 23.7 \\
\hline \multicolumn{6}{|c|}{ Balance of Zn } \\
\hline 1 - control & $0.75 \pm 0.004$ & $0.32 \pm 0.004$ & 42.6 & $62.6 \pm 0.004$ & 57.4 \\
\hline 2 - experimental & $0.75 \pm 0.004 * * \star$ & $0.47 \pm 0.004 * \star \star$ & 62.6 & $0.280 \pm 0.0004^{\star \star *}$ & 37.4 \\
\hline \multicolumn{6}{|c|}{ Balance of $\mathrm{Cu}$} \\
\hline 1 - control & $1.8 \pm 0.04$ & $0.8 \pm 0.04$ & 44.4 & $1.0 \pm 0.04$ & 55.6 \\
\hline 2 - experimental & $1.81 \pm 0.004$ & $1.1 \pm 0.04 * \star$ & 60.7 & $0.71 \pm 0.004^{\star \star \star}$ & 39.3 \\
\hline
\end{tabular}


The increase in the removal of lead, cadmium, zinc and copper from the poultry' body when using the silicon and mineral extract in their diet reduced the assimilation of heavy metals, in particular, of lead - by 27.5 percentage points, of cadmium - by 30.2 percentage points, of zinc - by 20.2 percentage points, and that one of copper - by 16.2 percentage points.

The decrease in the assimilation of heavy metals in the poultry's body positively affected the intensity of meat contamination by lead, cadmium, zinc and copper (Table 3).

Table 6. Impact of silicon and mineral extract on the concentration of heavy metals in poultry meat

Concentration of heavy metals $\mathrm{mg} \mathrm{kg}^{-1}$

\begin{tabular}{|c|c|c|c|c|c|c|c|c|}
\hline \multicolumn{9}{|c|}{$\begin{array}{l}\text { Control } \\
\text { Main diet }\end{array}$} \\
\hline Production & $\mathrm{Pb}$ & MAC & $\mathrm{Cd}$ & MAC & $\mathrm{Zn}$ & MAC & $\mathrm{Cu}$ & MAC \\
\hline White meat & $0.49 \pm 0.004$ & 0.5 & $0.08 \pm 0.004$ & 0.05 & $17.40 \pm 0.004$ & 70.0 & $0.48 \pm 0.004$ & 5.0 \\
\hline Red meat & $0.42 \pm 0.004$ & 0.5 & $0.16 \pm 0.004$ & 0.05 & $26.0 \pm 0.04$ & 70.0 & $0.91 \pm 0.004$ & 5.0 \\
\hline Liver & $0.46 \pm 0.004$ & 0.5 & $0.15 \pm 0.004$ & 0.05 & $26.45 \pm 0.004$ & 70.0 & $0.40 \pm 0.004$ & 5.0 \\
\hline \multicolumn{9}{|c|}{$\begin{array}{l}\text { Experimental } \\
\text { Main diet with silicon and mineral extract }\end{array}$} \\
\hline White meat & $0.44 \pm 0.004 * * *$ & 0.5 & $0.05 \pm 0.004 * *$ & 0.05 & $16.5 \pm 0.04 * \star \star$ & 70.0 & $0.37 \pm 0.004^{* \star *}$ & 5.0 \\
\hline Red meat & $0.41 \pm 0.004$ & 0.5 & $0.02 \pm 0.004 * \star *$ & 0.05 & $14.5 \pm 0.04^{* \star *}$ & 70.0 & $0.65 \pm 0.004^{* * *}$ & 5.0 \\
\hline Livere & $0.28 \pm 0.004 * * *$ & 0.5 & $0.12 \pm 0.004^{* *}$ & 0.05 & $20.4 \pm 0.04 * * *$ & 70.0 & $0.30 \pm 0.004^{* * *}$ & 5.0 \\
\hline
\end{tabular}

Thus, the use of silicon and mineral extract by young poultry during 130 days decreased the concentration of lead by 1.1 times in the white meat, by 1.02 times in the red meat and by 1.6 times in the liver. The concentration of cadmium in the white meat was by 1.6 times, in the red meat by 1.8 times and in the liver by 1.2 times lower in the poultry of the experimental group, compared to the control one. The concentration of zinc was lower by 1.05 times in the white meat, by 1.8 times in the red meat and by 1.3 times in the liver in the poultry of the experimental group. The concentration of copper in the white meat was by 1.3 times, in the red meat by 1.4 times and in the liver by 1.3 times lower compared to the control group. That is, the use of the silicon and mineral extract in the diet contributed to decrease the concentration of heavy metals in the liver, white and red meat of the poultry.

\section{Discussion}

The results of our research indicate the presence of contaminants in poultry diet components, including wheat, oats, barley, corn and sunflower meal. At the same time, exceeded maximum permissible concentrations. In particular, in grain of wheat, which is among the concentrated poultry feeds that is kept at home, an average of 55\%, an excess of cadmium and copper in 2.1 times and 2.0 times respectively. In the sunflower meal, an excess of the maximum permissible concentrations was observed in 3,0 times. The lowest levels of heavy metals such as lead, cadmium, zinc and copper were observed in corn grain.

\section{Conclusions}

The excess of MAC in cadmium by 2.1 times in the fodder wheat and by 3.0 times in the sunflower meal (Medical and Biological Requirements 5061-89) in the zone of intensive farming of the Right-bank Forest-steppe of Ukraine is observed.

The replacement of $10 \%$ of water with silicon and mineral water extract in the poultry' diet under their keeping at households contributes to increase the removal of lead from their bodies by $27.4 \%$, cadmium - by $30.2 \%$, zinc - by $20 \%$, and copper - by $16.3 \%$.

The use of silicon and mineral water extract in the poultry diet reduced the concentration of lead by 1.6 times in the liver, by 1.1 times in the white meat, and by 1.02 times in the red meat; it reduced the concentration of cadmium by $1.2,1.6$, and 1.2 times; zinc - by 1.3, 1.05, and 1.8 times, and copper - by 1.3, 1.3 and 1.4 times, respectively. 


\section{Acknowledgments}

The author expresses gratitude to the staff of the state institution Institute of Soil Protection for assistance in analyzing the material under investigation.

\section{References}

Awad, W.A., Bohm, J., Razzazi-Fazeli, E., Zentek, J. (2006). Effects of feeding deoxynivalenol contaminated wheat on growth performance, organ weights and histological parameters of the intestine of broiler chickens. Anim. Nutr. Anim. Physiol, 90, 32-37.

Baker, A. J. M., Mc Grath, C. M., Sidoli, R. D. (1994). Reeves An ecological risk assessment of heavy metal pollution of the agricultural ecosystem near a lead-acid battery factory. Resources, Conservation and Recycling, 11, 1-4, 41-49.

Beltcheva, M., Metcheva, R., Topashka-Ancheva, M., Popov, N., Teodorova, S. (2013). Zeolites versus Lead Toxicity. Bioequivalence and Bioavailability, 7(1), 12-29.

Bomko, V.S., Kuz'menko, O. A. (2006). Vivchennja optimal'nih rezhumiv zgodovuvannja mineral'noi dobavki saponit kurchatambrojleram. Agrarnivisti, 1, 10-13.

Bomko, V.S., Kuz'menko, O.A. (2007). Peretravnist' ta vikoristannja pozhivnih rechovin kurchatami-brojlerami pri riznih rezhimah zgodovuvannja dobavki saponitu. Agrarni visti, 2, 21-23.

Corzo, A., Moran, Jr., Hoehler, E. T. D., Lemmell, A. (2005). Dietary tryptophan need of broiler males from forty-two to fifty-six days of age. Poultry Science, 84, 226-231.

Dyachenko, L. S., Syvyk, T. L., Tytariova, O. M., Kuzmenko, O. A., Bilkevich, V. V. (2017). Natural detoxicants in pig rations and their impact on productivity and quality of slaughter products. Ukranian Journal of Ecology, 7(2), 239-246.

Dyachenko, L., Syvyk, T., Kosyanenko, O. (2015). Influence of different levels of cadmium in ration with natural detoxicant on performance, digestibility of substances and metabolism of nitrogen in young fattening pigs.technology of production and processing of livestock products, 1, 163-168.

El-Sharaky, A.S., Newiry, A.A., Badreldreen, M.M., Ewada, S. M., Shewieta, S.A. (2007). Protective role of selenium against renal toxity induced by cadmium in rats. Noxicology, 235, 185-193.

Fuzhu, L., Yankun, H., Zhuye, N. (2013). Effects of germanium on the growth of the main tissues and organs of the broilers. Acta Universitatis Agriculturalis Boreali-occidentalis, 29, 90-94.

Hauter, W. (2019). Poultry industry is costing us dearly. The Baltimore sun, 1. Available from: http://articles.baltimoresun.com/2012-05-17/news/bs-ed-perdue/.

Hutjens, M. F. (1991). Feedadditives. Vet. Clinics N. Am. Food Animal Pract., 5, 525-529.

Ibatullin, I. I. (2007). Godivlja silskogospodarskyh tvaryn: pidruchnyk [Feeding of farm animals: textbook]. Vinnycja : Nova knyga, 616 (in Ukrainian).

Ischenko, Ju. B. (2013). Dynamika vyrobnyctva produkcii ptahivnyctva v Ukrai'ni z 1990 roku i prognozy rozvytku galuzi do 2020 roku [The dynamics of poultry production in Ukraine since 1990 and forecasts for the development of the industry by 2020]. Poultry breeding of Ukraine and the world: management, analytics, reforms, standards. Available from: http://info.ptahokorm-union.com/ (in Ukrainian).

Kononenko, V. K., Ibatullin, V. S. (2000). Praktykum z osnov naukovyh doslidzhen u tvarynnyctvi [Workshop on the basis of research in animal husbandry]. Kyiv (in Ukrainian).

Kulyk, M. F., Kravciv, R. I., Obertuh, Ju. V. (2003). Kormy: ocinka, vykorystannja, produkcija tvarynnyctva, ekologija [Bars: valuation, use, livestock production, ecology]. Vinnycja: Tezys, 334 (inUkrainian).

Kurkina, S. V. (2001). Nadhodzhennja ta rozpodil vmistu vazhkyh metaliv v organah i tkanynah kurchat-brojleriv. [Receipt and distribution of heavy metal content in organs and tissues of broiler chickens]. Scientific and Technical Bulletin of the Institute of Animal Biology, Lviv, 1-2, 119-121 (in Ukrainian).

Kyryljuk, D.O. (2014). Analiz suchasnogo stanu rynku produkcii ptahivnyctva $v$ Ukraini [Analysis of the current state of poultry market in Ukraine]. Economy of agroindustrial complex, 2, 116-120 (in Ukrainian).

Malysh, N. (2009). Vazhki metaly u gruntah. [Heavy metals in soils] Scientific newsletter of NAU, 4, 67-71 (in Ukrainian).

Nedashkivska, N. V. (2015). Produktyvnist, obmin rechovyn ta mjasni jakosti kachenjat-brojleriv za zgodovuvannja polifunkcionalnogo sorbentu [Productivity, metabolism and meat quality of broiler chicken for feeding polyfunctional sorbent]. Bila cerkva (in Ukrainian).

Pirova, L.V., Sivic, T. L. (2010). Vplyv zhodovuvannya selenu na vmist vazhkyh metaliv u productakh zaboyu svyney [The effect of feeding selenium on the content of heavy heavy metals in pig slaughter products]. Scientific Bulletin of the Belotserkiv National Agrarian University, 2(70), 35-39.

Pogorjelov, M. V., Bumejster, V. I., Tkach, G. F. (2010). Makro- ta mikroelementy (obmin, patologija ta metody vyznachennja) [Macro- and trace elements (metabolism, pathology and determination methods)]: monografija. Sumy : Sumy State University (in Ukrainian).

Razanov, S. F. (2008). Sorbcijni vlastyvosti bdzholynogo pidmoru [Sorptional properties of sunflower].Scientific herald of the National University of Veterinary Medicine and Biotechnology them. S. Z. Gzhytsky, 12(4/45), 124-128 (in Ukrainian).

Razanov, S. F. (2010a). Bdzholynyj pidmor vyvodyt radionuklidy i vazhki metaly [Bee podmor releases radionuclides and heavy metals]. Apiary 3, 22-23 [in Ukrainian]. 
Razanov, S. F. (2010b). Efektyvnist kormovoi dobavky Apimoru pry godivli ptyci [The effectiveness of the feeding supplement of the Apimore poultry]. Letter of agricultural science, 10, 36-37 (in Ukrainian).

Razanov, S. F., Didur, I. M., Pervachuk, M. V. (2015). Efektyvnist znyzhennja zabrudnennja gruntiv svyncem i kadmijem za bdzholozapylennja silskogospodarskyh kultur v umovah ih mineralnogo pidzhyvlennja. Silske gospodarstvo ta lisivnyctvo [Efficiency of reducing soil pollution by lead and cadmium for bee pollination of agricultural crops under conditions of their mineral fertilization]. Agriculture and forestry, 2, 94-101 (in Ukrainian).

Reis, L.S. Pardo, P., Camargos, A.S., Oba, E. (2010). Mineral element and heavy metal poisoning in animals. Journal of Medicine and Medical Sciences, 1(12), 560-579.

Sendecka, S. V. (2014). Ptahivnyctvo v osobystyh seljans'kyh gospodarstvah: problemy i perspektyvy [Poultry farming in private farms: challenges and perspectives]. Science Herald LNUWMBT them. SZ Gzhytsky. Lviv, 1, 130-134 (in Ukrainian).

Simon, M. (2009). Handbook of Feed Additives. United Kingdom.

Sollrad, M., Wimmer, F. (2013). Germinated grain - healthy hens. Linz, 39-42.

Tkachuk O. P. (2016). Vplyv koncentracii' svyncju na zminu ekologo-agrohimichnyh pokaznykiv g'runtu [Influence of lead concentration on the change of ecological and agrochemical indicators of soil]. Agriculture and forestry, 3. $217-225$.

Toth, T., Hermann, M. R., Da Silva L. Montanarella.(2016). Heavy metals in agricultural soils of the European Union with implications for food safety. Environment International, 88. 2016, 299-309.

Wlazlo, L., Nowakowicz-Dębek, B., Kapica, J. (2016). Removal of ammonia from poultry manure by aluminosilicates. Journal of Environmental Management, 183, 722-725.

\section{Citation:}

Razanov, S.F., Hutsol, G.V., Posternak, L.I., Kovaleva, S.P. (2019). Effect of silicon and mineral extract on heavy metals balance and accumulation rate in the muscle tissue of poultry. Ukrainian Journal of Ecology, 9(4), 742-748.

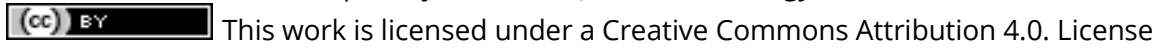

